\title{
Fluvial nutrient dynamics in a humanized landscape. Insights from a hierarchical perspective
}

\author{
E. Martí1,*, F. Sabater ${ }^{2}$, J.L. Riera ${ }^{1}$, G.C. Merseburger ${ }^{2}$, D. von Schiller ${ }^{1}$, A. Argerich ${ }^{2}$, \\ F. Caille ${ }^{3}$, and P. Fonollà ${ }^{1}$ \\ ${ }^{1}$ Unitat Asociada de Limnologia (CEAB-UB), Centre d'Estudis Avançats de Blanes (CSIC), Accés a la Cala \\ St. Francesc 14, 17300 Blanes, Spain \\ ${ }^{2}$ Departament d'Ecologia, Universitat de Barcelona, Diagonal 645, 08028 Barcelona, Spain \\ ${ }^{3}$ Institut de Ciència i Tecnologia Ambientals, Universitat Autònoma de Barcelona, 08193 Bellaterra, Spain \\ * Corresponding author: eugenia@ceab.csic.es
}

\begin{abstract}
Global change driven by human activity is overimposed on the hierarchical structure of fluvial ecosystems, causing a myriad of effects on their physical template and hydrology as well as on the quantity and quality of the resources for stream biota. Global change operates at all scales within this hierarchy, but its effects on the ecology of fluvial ecosystems at any particular scale may be exacerbated or overridden by concomitant effects occurring at other scales. The resulting effects can have major ecological implications on both ecosystem services (namely, biogeochemical processes associated to energy and matter flow) and biodiversity (namely, community structure), which currently are issues of central concern in environmental management. In this paper we focus on a particular ecological attribute of fluvial ecosystems, the capacity to process and retain nutrients, and examine how physical and chemical alterations caused by human activities, occurring at different scales, may interact to affect this capacity. We illustrate these effects based on existing knowledge and highlight the key changes at different scales which can be susceptible of major effects.
\end{abstract}

Keywords: stream, river, global change, nitrogen, phosphorus, biogeochemistry, hierarchical structure, nutrients.

\section{RESUMEN}

El cambio global derivado de la actividad humana se sobrepone a la estructura jerárquica de los ecosistemas fluviales, causando múltiples efectos sobre la estructura física, la hidrología, y la cantidad y calidad de los recursos para los organismos de los rios. El cambio global opera sobre todos los niveles de esta jerarquía estructural, pero sus efectos sobre la ecología de los ecosistemas fluviales en cada nivel pueden ser exacerbados o anulados por efectos que ocurren a otros niveles. Los efectos resultantes tienen implicaciones ecológicas tanto en relación con los servicios de los ecosistemas (por ejemplo, los procesos biogeoquímicos asociados al flujo de energía y materia) y la biodiversidad (por ejemplo, la estructura biótica de las comunidades). Actualmente, estos temas son una preocupación central en la gestión ambiental. En este artículo nos centramos en un atributo ecológico concreto de los ecosistemas fluviales, la capacidad de procesar y retener nutrientes, y examinamos cómo alteraciones físicas y químicas causadas por la actividad humana, que tienen lugar a diferentes niveles espaciales, pueden incidir en esta capacidad biogeoquímica. Estos efectos son ilustrados en base al conocimiento existente y enfatizan los cambios clave a diferentes niveles que pueden ser susceptibles de estos efectos.

Palabras clave: río, cambio global, nitrógeno, fósforo, biogeoquímica, jerarquía estructural, nutrientes.

"Flowing waters are really inspiring to the ecologists [...] The present problems of the oecumene re-emphasize the interest of the flowing waters or rivers as such and also as indicators of the 'health' of the landscapes." 


\section{INTRODUCTION}

Fluvial drainage networks receive materials that terrestrial systems have not retained (Hynes, 1975; Margalef, 1991; Likens \& Borman, 1995). This terrestrial export reaches streams and rivers mostly in pulses, which are to a great extent dictated by the hydrological regime imposed by the climate of each bioclimatic domain. Professor Margalef suggested that ecosystems are organized to process energy and matter in the most efficient way. Fluvial ecosystems are not an exception. Once terrestrially-derived materials enter these ecosystems, they undergo several retention and transformation processes as they are transported downstream. Ultimately, marine ecosystems receive the end products of fluvial processing. There is a growing body of evidence for this processing capacity and its implications on elemental biogeochemistry at different scales. For instance, quantification of nitrogen cycling processes at the reach scale in streams located across several biomes showed that these ecosystems retained on average $50 \%$ of nitrogen inputs from adjacent catchments (Peterson et al., 2001). At a larger scale, along the fluvial continuum, the intense utilization of the labile forms of the terrestrially-derived organic matter at the headwaters results in an export of recalcitrant material to downstream ecosystems (Raymond \& Bauer, 2001). Finally, in large river basins, such as the Amazon, biogeochemical processes may account for a relevant percentage of $\mathrm{CO}_{2}$ and $\mathrm{CH}_{4}$ losses to the atmosphere (Richey et al., 2002; Melack et al., 2004). Therefore, in contrast to previously thought, fluvial ecosystems can have an important role on global biogeochemical cycles.

Using a metaphor introduced by Professor Margalef (Margalef, 1997), we may picture river networks in the terrestrial landscape as analogous to the urinary system in the human body. Both systems are hierarchically organized, arranged along a unidirectional vector, and exert analogous functions within the largest organizational unit (i.e., the human body or the catchment), such as water balance and remo$\mathrm{val} /$ transformation of substances. The optimal operation of the urinary system ultimately relies on processes occurring at the lowest level, the nephrones, where the contact between substances and specialized cells is maximum. Likewise, the sediment-water interfaces could be viewed as the nephrones of the small-size streams (Boulton et al., 1998; Dahm et al., 1998). We can also argue that nephrones (being analogous to the processing hotspots sensu McClain et al., 2003) exist at all spatial scales from the microhabitats within a river sub-reach to the entire river network within the catchment. For example, microbial communities developed on cobbles (i.e., biofilms sensu Lock, 1993) may be considered as nephrones at the microhabitat scale (Battin et al., 2003), whereas floodplains (Forshay \& Stanley, 2005) or headwater streams (Lowe \& Likens, 2005) would act as nephrones at the river network scale. In accordance with hierarchy theory (O'Neill et al., 1989), the biogeochemical processing capacity at a particular spatial scale will be constrained by factors operating at larger scales and controlled by the capacity of the operational units (i.e., «the nephrones») at lower scales. Thus, the identification of operational units, the quantification of their processing capacity, and the elucidation of controlling factors are crucial to develop sound management strategies to preserve the integrity of these ecosystems.

Global change driven by human activities is overimposed on this hierarchical structure, causing a myriad of effects on the physical template of river networks (i.e., on their geomorphology and hydrology), as well as on the quantity and quality of energy and resources reaching these ecosystems. Understanding the interplay between the pattern of human impacts and the fluvial hierarchy is crucial because it has major implications for both ecosystem services (biogeochemical processes associated to energy and matter flow) and biodiversity (community structure), which are central concerns in environmental management (Palmer et al., 2004). Pressures derived from human activities may manifest themselves at all scales within the hierarchical organization of the fluvial ecosystems, and frequently are multiple, interacting 


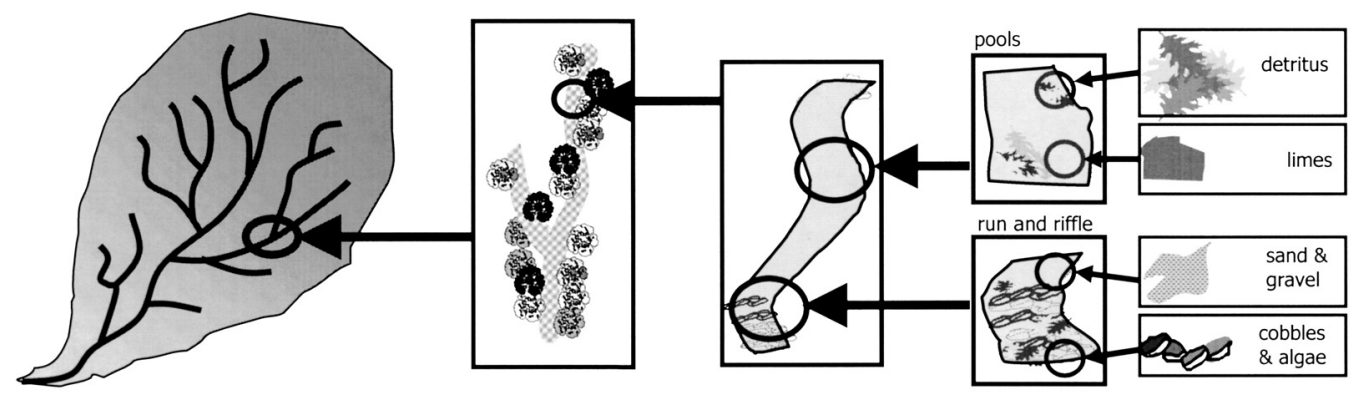

\begin{tabular}{|c|c|c|c|c|}
\hline & Catchment & Section & Reach & $\begin{array}{l}\text { Sub-reach } \\
\text { and microhabitat }\end{array}$ \\
\hline Morphology & Network configuration & Sinuosity & $\begin{array}{c}\text { Constrain and } \\
\text { unconstrain channel }\end{array}$ & Substrate type \\
\hline Hydrology & $\begin{array}{l}\text { Expansion/ } \\
\text { contraction }\end{array}$ & $\begin{array}{l}\text { Lateral } \\
\text { linkages }\end{array}$ & Vertical linkages & \\
\hline $\begin{array}{l}\text { Human } \\
\text { activity }\end{array}$ & $\begin{array}{l}\text { Distribution and } \\
\text { type of human activities }\end{array}$ & $\begin{array}{l}\text { Riparian removal } \\
\text { Floodplain } \\
\text { disconnection }\end{array}$ & Channelization & Sediment clogging \\
\hline
\end{tabular}

Figure 1. Relevant scales for the analysis of fluvial ecosystems (modified from Frissell et al., 1986). The table below illustrates some of the factors affecting nutrient retention capacity at each scale with respect to morphology and hydrology and it also shows examples of human activities that may interact with these factors. Esquema de los niveles de organización espacial relevantes para el análisis de los ecosistemas fluviales (modificado a partir de Frissell et al., 1986). La tabla muestra algunos de los factores que afectan la capacidad de retención en los distintos niveles en relación a factores morfológicos e hidrológicos, y también muestra ejemplos de actividades humanas que pueden interactuar con estos factores.

among them. Often, the result of this interaction is additive or synergistic, leading to cumulative impacts downstream the river network (Webster et al., 1992; Scott et al. 2002). But it may also be antagonistic, in which case different impacts (with single or multiple causes) will tend to override each other, leading to compensatory effects. Here we attempt to conceptually reconcile the diverse scales of operation of fluvial ecosystems and human activities. We further advocate the need to examine explicitly the mode of interactions between human impacts on streams and rivers, and stress the importance of identifying the scales at which impacts operate.

To develop this conceptual approach, we focus on a particular ecological attribute of fluvial ecosystems: their capacity to process and retain nutrients. First, we introduce the biogeochemical processing capacity of fluvial ecosystems and identify some factors controlling it at different spatial scales (sensu Frissell et al., 1986). Next, we consider how human activities influence nutrient availability and flux regime in fluvial ecosystems and discuss which particular effects take place at different spatial scales. Finally, we exemplify the resultant effects from the interaction of human activities operating at different scales on fluvial nutrient processing capacity, which can be either synergistic or antagonistic. Rather than reviewing the existing literature, we provide an illustration of our conceptual ideas with particular examples, some of which arise from our 15 years of research on stream biogeochemistry.

\section{THE BIOGEOCHEMICAL PROCESSING CAPACITY OF FLUVIAL ECOSYSTEMS}

Over the last 25 years, the nutrient spiralling concept (Webster \& Patten, 1979; Newbold et al., 1981) has provided an excellent research arena to increase our understanding of nutrient 
retention and transformation capacity in fluvial ecosystems. In essence, this concept conciliated nutrient cycling with the downstream transport, which is a major characteristic of these ecosystems. It also provided the mathematical basis for quantifying this capacity in terms of the distance travelled by atoms or molecules as they complete a cycle (i.e., the spiralling length). Although the nutrient spiralling concept can be applied to any spatial scale up to the entire river network (Fisher et al., 2004), methodological and operational constrains have limited the empirical quantification of nutrient spiralling metrics (Stream Solute Workshop, 1990) to the reach scale in relatively small size streams. Many studies using this empirical approach have revealed that small streams act as relevant «nephrones» within river networks (Lowe \& Likens 2005). Other empirical approaches, however, have also evidenced the high biogeochemical processing capacity of other components of the river networks, such as floodplains (Venterink et al., 2003, Forshay \& Stanley, 2005) or riparian zones (Gregory et al., 1991; Naiman \& Décamps, 1997; Sabater et al., 2003). Together, all these studies stress the high potential of fluvial ecosystems to transform and retain the materials exported from the adjacent terrestrial ecosystems. Nevertheless, there is still a need to develop methodologies, especially for large rivers, that will allow us to use a common currency to compare the biogeochemical processing capacity within components at a particular scale and across scales. The disconnection between measurements and empirical approaches at different spatial scales challenges an integrative view of the overall relevance of river networks within the context of terrestrial-aquatic biogeochemistry (but see Grimm et al., 2003).

The biogeochemical processing capacity of streams and rivers is ultimately dictated by the communities (mostly microbial) that develop in these ecosystems. At each spatial scale, the physical template determines the existence of components, or operational units, characterized by distinct communities and their associated biogeochemical processes (Fig. 1). Within each of these operational units, rates of nutrient retention and transformation are influenced by the availability of energy and resources, and vary temporally in accordance with the regime of resource availability. Empirical evidence of the functional contrast between units can be found at all spatial scales (Dent et al., 2001). At the microhabitat scale, results from Battin et al. (2003) and Sabater et al. (2002) show that biogeochemical response differs between biofilms of different structure and biological composition. At the reach scale, several studies have evidenced contrasting chemical composition between the surface stream and the riparian, hyporheic, and parafluvial zones, which is indicative of different biogeochemical responses (Martí et al., 2000, Bernal, 2006). Differences in nutrient retention efficiency measured between reaches of different morphology (Martí \& Sabater, 1996) or parent lithology (Valett et al., 1996) are indicative of biogeochemical variability among units at the section scale. Finally, even though fluvial nutrient processing capacity is associated with hot spots and hot moments (McClain et al., 2003) and hence subject to large spatial and temporal heterogeneity, several studies suggest that there are also regularities at the river network scale. Of these, the most obvious one is the general increase in nutrient processing capacity and concomitant decrease in processing efficiency from low order streams towards higher order stream reaches (Sabater \& Martí, 2002). This pattern is associated with changes in discharge, water velocity and background nutrient concentrations as we move downstream from headwaters, and is ultimately explained by the geomorphic template imposed by the physiographic characteristics of the catchment. Despite this longitudinal continuum, characterization of discrete operational units within the river network can also be made based on the distinct hydromorphological features that characterize each stream or river order.

Because fluvial ecosystems are spatially organized, the diversity and spatial configuration of the operational units at a given spatial scale will determine the final biogeochemical processing capacity at this scale (Fisher et al., 1998a). In this context, hydrological linkages among units play 
an important role in fluvial biogeochemistry (Fisher et al., 1998b; Tockner et al., 1999; Dent el al., 2001). These linkages facilitate the contact between solutes and organisms and the flux of nutrients among units, and determine the expansion of the biogeochemical reactivity at each spatial scale (see for example, Stanley et al., 1997 at the river network scale). However, it is worth noticing that the spatial configuration of units within a particular scale is not random, but rather constrained by the physical template ultimately imposed by the physiographic features of the catchment. For this reason, and because each unit has a particular biogeochemical capacity, the direction of the hydrological linkage among units is an additional factor determining the biogeochemical response at a given scale. For instance, Henry \& Fisher (2003) demonstrated that the flow direction between the surface water and the parafluvial zone was determinant for the development of algal communities at these surfacesubsurface interfaces and showed that this had important implications for nitrogen cycling. Other examples can be found for the flow direction between the stream channel and the riparian zone (Martí et al., 2000) and between the river channel and floodplains (Tockner et al., 1999). At the river network scale, although climate can determine the overall surface to sub-surface direction of flow (gaining or losing streams/rivers); the unidirectional flow ultimately imposes the dominant connection among units. At this scale, the configuration of river networks can be a major factor influencing nutrient exports to marine ecosystems (Malard et al., 2002; Poole, 2002; Wiens, 2002; Benda et al., 2004).

Multiple factors, acting at distinct spatial and temporal scales, have been identified that affect nutrient dynamics in streams and rivers (Fig. 1). First and foremost is hydrology, which plays a major role in fluvial biogeochemical capacity not only because it is largely responsible for the regime of nutrient availability, but also because it conditions the relative influence of this capacity on overall nutrient transport. For instance, many studies have shown that in headwater streams nutrient retention efficiency is lower at higher discharge (Butturini \& Sabater, 1998;
Peterson et al., 2001; Wollheim et al., 2001; Hall et al., 2002; Simon et al., 2005). In contrast, increases in discharge in large rivers facilitate the movement of nutrients into floodplains where they are effectively processed, resulting in a higher overall retention (Junk et al., 1989; Tockner et al., 2000; Valett et al., 2005). Besides hydrology, patterns of temporal variation in biogeochemical response are influenced by particular environmental factors operating at each scale. For example, in a temperate headwater stream with well developed riparian vegetation, annual variation of phosphate retention efficiency at the reach scale was related to the availability of organic matter (Mulholland et al., 1985), whereas in a Mediterranean stream with open canopy it was related to the development of photosynthetic primary producers (Martí \& Sabater, 1996). Other studies have related annual temporal variability in stream nutrient retention to water temperature (Butturini \& Sabater, 1998; Simon et al., 2005), light availability to stream communities (Mulholland, 2004), biological demand (Hall \& Tank, 2003), and nutrient availability (Dodds et al., 2002). Temporal variation in nutrient retention response can also occur at shorter time-scales, such as the diurnal cycle. Daily variations in nutrient concentrations observed in surface waters are evidence of this (Grimm, 1987). Taking an experimental approach, Martí et al. (1994) also showed that nutrient retention efficiency tended to be higher during day-time than at night in two Mediterranean streams; however, day-to-night differences varied over the year and did not exceed annual variation. These examples show that multiple factors can interact in time to create moments of minimum, intermediate and maximum biogeochemical processing capacity.

The coupling between these moments and the nutrient flux regime entering the fluvial ecosystem will finally determine the export of nutrients to marine ecosystems. Human activities can directly or indirectly influence these factors (Fig. 1) and, consequently, modify the biogeochemical processing capacity of these ecosystems. In the next section we describe the human fingerprint on these controlling factors. 


\section{RIVER NETWORKS IN A HUMANIZED LANDSCAPE}

We live in a human dominated and transformed planet. River networks perfuse through landscapes on which humans have developed for centuries. Historically, human pressure on fluvial ecosystems was generally modest in magnitude and local in scale. However, after the industrial revolution, the human fingerprint on the landscape has both intensified and expanded significantly (Meybeck, 2003; Allan, 2004). This intensification is related to technological developments and the need to supply with resources an increasing human demand with significant changes in societal habits. The expansion is associated to the use of larger areas of the landscape for both urban development and agricultural practices and with the emission of chemical components to the atmosphere. Due to their position in the landscape, fluvial ecosystems are paradigmatic integrators of human impacts on terrestrial catchments. Major consequences of current human activity on fluvial ecosystem biogeochemistry may be summarized as the modification of hydrologic resources, the increase in the availability of elements essential to organisms, and the introduction of chemical compounds which are "exotic" to biota (Meybeck, 2003). In this context, and mostly due to the atmospheric emissions, virtually no river network is exempted of human influence. Thus, understanding the dynamics of fluvial communities and their associated biogeochemical processes must include the consideration of human-induced impacts on these ecosystems. In fact, this consideration has opened an extensive research arena over the last decade.

Human activities impinge on fluvial ecosystems at different spatial scales (Fig. 1). For instance, human environmental effects can range from point source nutrient inputs at the reach scale to nitrogen atmospheric deposition at the

Table 1. Examples of environmental modifications caused by human activities having direct or indirect effects on fluvial ecosystems biogeochemistry. The table also shows the spatial scale within the drainage network where these modifications operate. Ejemplos de modificaciones ambientales, causadas por distintas actividades humanas, que tienen un efecto directo o indirecto sobre la biogeoquímica de los ecosistemas fluviales. La tabla también muestra el nivel espacial dentro de la red de drenaje donde estas modificaciones operan.

Environmental modifications by human activities

Atmospheric deposition

Climate change
Spatial scale of operation

Trans-catchment

Diffuse soil pollution

Modification of vegetation cover

Change in runoff pathways

Catchment

Modification of flow regimes

Changes in sediment erosion/transport

Deforestation of riparian zones

Loss of floodplains

Changes in sedimentation patterns

Section

Modification of flow regimes (impoundments, diversions)

River sinuosity simplification

In-channel modifications (straightening, canalization, dredging)

River bank modifications (reinforcements, artificial verms, etc)

Control of aquatic vegetation

Reach

Point source inputs

Sediment siltation 
catchment scale and beyond. Successful management of streams and rivers begins with the identification of impacts and their origins (Gergel et al., 2002). However, it is worth noticing that the spatial scale at which human activities operate is not always directly linked to the spatial scale at which their effects are observed in the fluvial ecosystem. Thus the challenge arises to identify the relevant scales associated with a given pressure so that corrective or palliative measures can be applied at the appropriate scales. To illustrate this argument, below we provide some examples of human activities having effects at particular spatial scales of fluvial ecosystems. A summary of human pressures and the scale at which they operate is presented in Table 1.

Atmospheric emissions from industrial practices and transportation are a source of nutrients and toxic substances (volatile organic compounds) to the biosphere. They have also been identified as the major cause of current climate change (Kyoto Protocol, United Nations Framework Convention on Climate Change, 1997). Although emissions originate at local scale (but they can also be diffuse, as in automobile fumes), the atmosphere acts as a distribution vector and ultimately their effects operate at catchment and even trans-boundary catchment scales. Atmospheric nitrogen deposition is an important source of nitrogen to catchments, causing an increase in nitrogen concentrations in streams and rivers (Carpenter et al., 1998; Boyer et al., 2002; Zak et al., 2004), even in relatively pristine catchments. Hydrological regime, especially of large rivers, can also be vulnerable to atmospheric emissions through their effect on the climate, as shown, for instance, by the significant increases in discharge that have been observed in rivers of the Pan-Artic (Peterson et al., 2002), which are located in remote areas far away from emission sources.

Agricultural practices operate at the catchment or sub-catchment scales and significantly contribute to increased circulation of bioavailable elements. A fraction of these additional elements reach streams and rivers through diffuse pathways affecting either entire river networks or large sections of them. About 90 percent of the phosphorus mined annually is used to produce fertilizers and animal feeds, and it has been estimated that annual accumulation of phosphorus in the Earth's freshwater and terrestrial ecosystems has almost quadrupled since humans began farming on a large scale (Bennett \& Carpenter 2002). Likewise, riverine nitrogen fluxes in many of the temperate regions have increased from pre-industrial times by 2 to 20 fold (Howarth et al., 1996; Green et al., 2004), with agricultural practices being one of the major causes. Evidence of this land use effect is the observation that the export of nitrogen and phosphorus by streams and rivers increases as the proportion of agricultural land in the watershed increases (Jordan et al., 1997; Withers \& Lord, 2002). Due to the different chemical properties of nitrogen and phosphorus, land-based human activities, such as agriculture, not only severely increment the amount of nutrients reaching fluvial ecosystems, but also affect their relative proportions (i.e., their stoichiometry) (Bennett et al., 2001).

Agriculture also modifies hydrologic pathways through changes in the vegetation cover (Sahin \& Hall 1996; Brown et al., 2005) and the creation of impoundments, irrigation infrastructures and inter-catchment diversions. In addition, it alters the total amount of available hydrologic resources. Currently, humans use $54 \%$ of the accessible runoff of the Earth, or $30 \%$ of accessible terrestrial freshwater supply (Postel, 1998). Of this, the major use by far is in agriculture $(65 \%)$ and industry $(22 \%)$. It has been calculated that by the end of this century the flow of about two-thirds of the rivers of the world will be regulated (Vitousek et al., 1997). This has a clear effect on the water residence time and the amount of water flowing through particular sections of the rivers and streams and ultimately on the entire river network.

Industrial, urban and agricultural practices also result in direct effects at the section and reach scale through the modification (or even elimination) of riparian zones and river floodplains, 
which are key biogeochemical components of the fluvial ecosystems (Gregory et al., 1991; Sabater et al., 2003) and exert a strong control on the ecology of the river channels (Sparks, 1995; Sabater et al., 2000; Simon \& Collison, 2002). In addition, these activities have promoted the canalization of sections of streams and rivers for protection against floods (Hohensinner et al., 2004). All these actions result in a decrease of vertical and lateral hydrological connections and a simplification of habitat heterogeneity, with direct negative consequences for the biogeochemical processing capacity at the reach scale (SánchezPérez \& Trémolières, 2003).

Finally, although urban activity mainly operates at the sub-catchment and section scales (Meyer et al., 2005), the waste water resulting from this activity has a clear local effect on fluvial ecosystems. For instance, the point source inputs from wastewater treatment plants vary the hydrological regime and increase nutrient concentrations of streams and rivers. This activity can additionally have an indirect effect at an even smaller scale, by clogging the sediment-water interfaces with suspended organic particles. This may decrease the vertical exchange of water and solutes with the biogeochemically active hyporheic zone (Packman \& Mackay, 2003; Rauter et al., 2005).

In sum, effects of human activities on fluvial ecosystems have their origin and operate at multiple spatial scales. Our examples also illustrate the fact that effects at the larger scales are mostly associated to alterations of chemical and hydrological properties, whereas at lower scales they also involve modifications of morphological and hydraulic properties of these ecosystems. Often, multiple effects can be identified (Scott et al., 2002). This raises the important question of whether they interact and how. Are the interactions cumulative or even synergistic, magnifying the effects of separate impacts? Or are there cases were the interactions are antagonistic or compensatory? We argue that identifying impacts and their causes may be insufficient for sound fluvial ecosystem management unless their ways of interaction are also taken into account.

\section{MULTICAUSATIVE HUMAN-DERIVED EFFECTS ON FLUVIAL BIOGEOCHEMICAL CAPACITY: THE IMPORTANCE OF SCALE CONSIDERATION}

"For most topics that concern ecology, I like poets more than lawyers, and feel more inclined to fantasy, feeling and inspiration than to rigor, consistency and even responsibility. In my views on environmental problems, I feel more attracted by the origin of the troubles and what they tell us about the workings of the biosphere than by their solutions, at least in the way the problem is usually faced at present."

\section{R. Margalef (Our Biosphere, 1997)}

As described in the previous section, results from human activities can operate at different scales, from entire catchments to particular reaches; and their effects can modify both the physical template and available resources, which have been shown to play a relevant role on the control of fluvial biogeochemical processes. In addition, the results from multiple activities may co-exist in time and space, but the final effect does not necessarily follow and arithmetic relation. In fact, the effects of some activities may perfuse through spatial scales, while others may be buffered. In this section, we argue that the human-derived effects on the biogeochemistry of fluvial ecosystems are most frequently multicausative, and, at a particular spatial scale, can either be exacerbated (i.e., cumulative or synergistic effects) or overridden (i.e., antagonistic or compensatory effects) by concomitant effects occurring at other scales. For a long time, biogeochemistry of fluvial ecosystems focused on near pristine sites, in an effort to avoid confounding natural controls and controls derived from human-activities. Nowadays, we are faced with a large ongoing experiment in nature, which is mostly induced by human changes. This poses serious problems for us, as a society, because it compromises our basic resources. However, as scientists, this is a great challenge to gain insight on those controls and mechanisms that drive biogeochemical processes in fluvial ecosystems because human-induced 
changes magnify ranges of key ecological variables beyond their natural variability. Our argumentation aims at bringing a conceptual perspective to approach this challenge. In the next paragraphs we present some examples from existing knowledge to illustrate this perspective.

The urban use of water resources has clearly contributed to the eutrophication of running waters (Walsh et al., 2005). Waste water from urban areas enters streams and rives mostly at discrete locations through the river network, creating abrupt chemical discontinuities along the upstream-downstream continuum even when technological palliatives to reduce nutrient loads, such as waste water treatment plants, are implemented. Some studies show that receiving streams have a certain capacity to retain and transform point source inputs (Haggard et al., 2001; Martí et al., 2004; Merseburger et al., 2005); and thus, to partially buffer the effects of urban activity at the reach or section scales. However, they also evidence that the stream efficiency to remove nutrients is significantly lower than that from non-polluted streams of similar size (Martí et al., 2004). This is basically attributed to nutrient concentrations above the saturation levels of stream communities, and it is supported by results from studies that show lower stream nutrient demand in streams with higher nutrient concentration (Dodds et al., 2002; Merseburger, 2006). The magnitude of the point source effect, however, may be modulated by the local conditions. For instance, small streams or streams and rivers located in arid regions are the most vulnerable to point source effects because they are more likely to have lower ratios between the discharge of recipient streams or rivers and the effluent flow. In this sense, increasing human demand of hydrologic resources may exacerbate point source effects from urban areas and promote cumulative impacts along the river network. In addition, simplification of the channel morphology of the recipient streams or rivers through engineering practices can exacerbate the point source effect on stream biogeochemical processes, as suggested by results from Grimm et al. (2005). Finally, there are evidences that in rural areas, additional inputs through diffuse sources from agricultural fields can overwhelm point source effects on stream biogeochemical processes (Merseburger et al., 2005). Together, these results illustrate how a human activity operating at the sub-catchment or section scale has direct biogeochemical effects at the reach scale, which can be exacerbated by concomitant direct effects at this scale (i.e., reach canalization) or at larger scales (i.e., water withdrawn), or overridden by indirect effects from activities operating at the catchment or section scale (i.e., agricultural practices).

At the other extreme of causes of freshwater eutrophication are agricultural practices, which act at the catchment or sub-catchment scale. This activity increases nutrient loads, especially of nitrogen, in streams and rivers (Boyer et al., 2002). Extensive urbanization may also contribute to this increase in a similar fashion (Meyer et al., 2005). Unlike urban activities in concentrated areas, nutrients from agricultural practices or extensive urbanization reach fluvial ecosystems through diffuse pathways, and thus, can affect large sections of river networks. In this situation, maintenance of natural riparian vegetation may counteract diffuse nutrient inputs (Naiman \& Décamps, 1997; Sabater et al., 2003). Riparian forests not only act as buffers preventing nutrients derived from human activities in the catchment from entering streams and rivers, but also hydrological linkages between surface channels and riparian zones may contribute to increase the overall ecosystem nutrient retention (Schade et al., 2005). Nevertheless, riparian zones are highly vulnerable to human activities that directly remove vegetation from these zones or disconnect riparian strips from active channels, through levees construction, to gain land for development (Hohensinner et al., 2004). Removal of riparian vegetation associated to agricultural practices has been shown to alter hydraulic geomorphology of stream channels, which in turn has consequences on the nutrient processing capacity. For instance, Sweeney et al. (2004) demonstrated that forested reaches, with a wider and more natural configuration, were able to take up more nitrogen and process greater amounts of organic matter 
per unit channel length than deforested reaches with more incisive channels. In contrast, Sabater et al. (2000) found higher retention efficiency for nitrogen and phosphorous in a logged than in a forested reach of a near pristine stream. In this case, the increase in nutrient retention efficiency was attributed to an increase in stream algal growth after vegetation removal. In interpreting these contrasting results one must take into account both the time scale of the studies (i.e., the second one revealed shorter-time scale results) and the conditions of nutrient availability (i.e., the second study was conducted in a stream draining a non-humanized catchment and having low nutrient concentrations). Taking all results together, we can suggest that streams and rivers receiving high nutrient loads are highly vulnerable to morphological human-driven alterations. These alterations operate directly at the reach scale or can be derived from practices operating at a larger scale, and reduce the surface hydrological linkages with sub-surface bioreactive components. Consequently, they significantly reduce the potential of nutrient retention and transformation within the fluvial ecosystems. This example illustrates how effects of activities at a large scale (i.e., the catchment) can perfuse to lower scales (i.e., sections) resulting in synergistic negative effects on fluvial biogeochemical processes, although at short-time scales or under particular conditions (i.e., low nutrient concentrations) the effects can be compensatory.

These two examples have implications that go beyond a purely scientific interest in fluvial biogeochemistry. They highlight the fact that land management decisions and associated activities can have wide repercussions on the integrity of river ecosystems (including their biogeochemical processing capacity) at varying scales, through diverse pathways and involving complex interactions. How the spatial and temporal patterns of human activities on the catchment interact with the river network is seldom obvious, yet understanding this interaction is crucial for successful integrated catchment management. For instance, Alexander et al. (2000) examined the sources of nutrient inputs and the variations in in-stream nutrient retention across the Mississippi river catchment and concluded that the large nutrient exports to the Gulf of Mexico were highly driven by the distribution and type of human activities within the drainage network.

The net result of all concurring impacts is often cumulative, mostly leading to the dysfunctionality of river network «nephrones», but at certain scales and for certain ecosystem attributes, compensatory responses may dampen the negative effects of human impacts. This stresses the need for a spatially-explicit perspective on river management, which is already perceived as important, but also the need to consider both the scale of operation of human activities and their multi-causative effects on stream ecology and their interactions. This can only be accomplished if we manage to bridge research at the reach scale and below with research at the landscape and river network scale. Therein lays the frontier for fluvial biogeochemical research for the decades to come.

\section{ACKNOWLEDGEMENTS}

This article is dedicated to the memory of Professor Ramon Margalef, who directly or indirectly vested each of us with a profound interest in the ecology of streams. Professor Margalef would occasionally ask us if we had considered the possibility of changing the music we were playing. After fifteen years of research, we acknowledge that we may have changed the instruments, but we believe that in this research arena there is still a lot to be played to reach a perfect opera. Thank you, Professor Margalef, for your everlasting inspiration.

\section{REFERENCES}

ALEXANDER, R. B., R. A. SMITH \& G. E. SCHWARZ. 2000. Effect of stream channel size on the delivery of nitrogen to the Gulf of Mexico. Nature, 403: 758-761.

ALLAN, J. D. 2004. Landscape and riverscapes: The influence of land use on stream ecosystems. Ann. Rev. Ecol. Evol. Syst., 35: 257-284. 
BATTIN, T. J., L. A. KAPLAN, J. D. NEWBOLD \& C. M. E. HANSEN. 2003. Contributions of microbial biofilms to ecosystem processes in stream mesocosms. Nature, 426: 439-442.

BENDA, L., N. L. POFF, D. MILLER, T. DUNNE, G. REEVES, G. PESS \& M. POLLOCK. 2004. The network dynamics hypothesis: how channel networks structure riverine habitats. BioScience, 54: 413-427.

BENNETT, E. M. \& S. R. CARPENTER. 2002. P soup (the global phosphorus cycle). World Watch Magazine, March/April: 24-32.

BENNETT, E. M., S. R. CARPENTER \& N. F. CARACO. 2001. Human impact on erodable phosphorus and eutrophication: a global perspective. BioScience, 51: 227-234.

BERNAL, S. 2006. Nitrogen storm responses in an intermittent Mediterranean stream. PhD thesis. Barcelona University. $235 \mathrm{pp}$.

BOULTON, A. J., S. FINDLAY, P. MARMONIER, E. H. STANLEY \& H. M. VALETT. 1998. The functional significance of the hyporheic zone in streams and rivers. Ann. Rev. Ecol. Syst., 29: 59-81.

BOYER, E. W., C. L. GOODALE, N. A. JAWORSKI \& R. W. HOWARTH. 2002. Anthropogenic nitrogen sources and relationships to riverine nitrogen export in the Northeastern USA. Biogeochemistry, 57/58: 137-169.

BROWN, A. E., L. ZHANG, T. A. McMAHON, A. W. WESTERN \& R. A. VERTESSY. 2005. A review of paired catchment studies for determining changes in water yield resulting from alterations in vegetation. J. Hydrol., 310: 28-61.

BUTTURINI, A., \& F. SABATER. 1998. Ammonium and phosphate retention in a Mediterranean stream: hydrological versus temperature control. Can. J. Fish. Aquat. Sci., 55: 1938-1945.

CARPENTER, S. R., N. F. CARACO, D. L. CORRELL, R. W. HOWARTH, A. N. SHARPLEY \& V. H. SMITH. 1998. Nonpoint pollution of surface waters with phosphorus and nitrogen. Ecol. Appl., 8: 559-568.

DAHM, C. N., N. B. GRIMM, P. MARMONIER, H. M. VALETT \& P. VERVIER. 1998. Nutrient dynamics at the interface between surface waters and groundwaters. Freshwat. Biol., 40: 427-451.

DENT, C. L., N. B. GRIMM \& S. G. FISHER. 2001. Multi-scale effects of surface-subsurface exchange on stream water nutrient concentrations. J. N. Am. Benthol. Soc., 20: 162-181.

DODDS, W. K., A. J. LOPEZ, W. B. BOWDEN, S. GREGORY, N. B. GRIMM, S. K. HAMILTON, A.
E. HERSHEY, E. MARTÍ, W. H. MCDOWELL, J. L. MEYER, D. MORRALL, P. J. MULHOLLAND, B J. PETERSON, J. L. TANK, H. M. VALETT, J. R. WEBSTER \& W.M. WOLLHEIM. 2002. N uptake as a function of concentration in streams. J. N. Am. Benthol. Soc., 21: 206-220.

FISHER, S. G., N. B. GRIMM, E. MARTÍ \& R. GÓMEZ. 1998a. Hierarchy, spatial configuration, and nutrient cycling in a desert stream. Aust. J. Ecol., 23: 41-52.

FISHER, S. G., N. B. GRIMM, E. MARTÍ, R. M. HOLMES \& J. B. JONES, Jr. 1998b. Material spiraling in stream corridors: a telescoping ecosystem model. Ecosystems, 1: 19-34.

FISHER, S. G., R. A. SPONSELLER \& J. B. HEFFERNAN. 2004. Horizons in stream biogeochemistry: flowpaths to progress. Ecology, 85: 2369-2379.

FRISSELL, C. A., W. J. LISS, C. E. WARREN \& M. D. HURLEY. 1986. A hierarchical framework for stream habitat classification: viewing streams in a watershed context. Environ. Manage., 10: 199-214.

FORSHAY, K. J. \& E. H. STANLEY. 2005. Rapid nitrate loss and denitrification in a temperate river floodplain. Biogeochemistry, 75: 43-64.

GERGEL, S. E., M. G. TURNER, J. R. MILLER, J. M. MELACK \& E. H. STANLEY. 2002. Landscape indicators of human impacts to riverine systems. Aquat. Sci., 64: 118-128.

GREEN, P. A., C. J. VÖRÖSMARTY, M. MEYBECK, J. N. GALLOWAY, B. J. PETERSON \& E. W. BOYER. 2004. Pre-industrial and contemporary fluxes of nitrogen through rivers: a global assessment based on typology. Biogeochemistry, 68: 71-105.

GRIMM, N. B. 1987. Nitrogen dynamics during succession in a desert stream. Ecology, 68: 1157-1170.

GRIMM, N. B., S. E. GERGEL, W. H. McDOWELL, E. W. BOYER, C. L. DENT, P. M. GROFFMAN, S. C. HART, J. W. HARVEY, C. A. JOHNSTON, E. MAYORGA, M. E. MCCLAIN \& G. PINAY. 2003. Merging aquatic and terrestrial perspectives of nutrient biogeochemistry. Oecologia, 137: 485-501.

GRIMM, N. B., R. W. SHEIBLEY, C. L. CRENSHAW, C. N. DAHM, W. J. ROACH \& L. H. ZEGLIN. 2005. N retention and transformation in urban streams. J. N. Am. Benthol. Soc., 24: 626-642.

GREGORY, S. V., F. J. SWANSON, W. A. McKEE \& K. W. CUMMINS. 1991. An ecosystem perspective of riparian zones. BioScience, 41: 540-551.

HAGGARD, B. E., D. E. STORM \& E. H. STANLEY. 2001. Effects of a point source input 
on stream nutrient retention. J. Am. Water Resour. Assoc., 37: 1291-1299.

HALL, R. O., Jr., E. S. BERNHARDT \& G. E. LIKENS. 2002. Relating nutrient uptake with transient storage in forested mountain streams. Limnol. Oceanogr., 47: 255-265.

HALL, R. O., Jr., \& J. L. TANK. 2003. Ecosystem metabolism controls nitrogen uptake in streams in Grand Teton National Park, Wyoming. Limnol. Oceanogr., 48: 1120-1128.

HENRY, J. C. \& S. G. FISHER. 2003. Spatial segregation of periphyton communities in a desert stream: causes and consequences for $\mathrm{N}$ cycling. $J$. N. Am. Benthol. Soc., 22: 511-527.

HOHENSINNER, S., H. HABERSACK, M. JUNGWIRTH \& G. ZAUNER. 2004. Reconstruction of the characteristics of a natural alluvial river-floodplain system and hydromorphological changes following human modifications: the Danube River (1812-1991). River. Res. Appl.. 20: 25-41.

HOWARTH, R. W., G. BILLEN, D. SWANEY, A. TOWNSEND, N. JAWORSKI, K. LAJTHA, J. A. DOWNING, R. ELMGREN, N. CARACO, T. JORDAN, F. BERENDSE, J. FRENEY, V. KUDEYAROV, P. MURDOCH \& Z. ZHAO-LIANG. 1996. Regional nitrogen budgets and riverine $\mathrm{N} \& \mathrm{P}$ fluxes for the drainages to the North Atlantic Ocean: natural and human influences. Biogeochemistry, 35: 75-139.

HYNES, H. B. N. 1975. The stream and its valley. Verh. Internat. Verein. Limnol., 19: 1-15.

JORDAN, M. J., K. J. NADELHOFFER \& B. FRY. 1997. Nitrogen cycling in forest and grass ecosystems irrigated with ${ }^{15} \mathrm{~N}$-enriched wastewater. Ecol. Appl., 7: 864-881.

JUNK, W. J., P. B. BAYLEY \& R. E. SPARKS. 1989. The flood pulse concept in river-floodplain systems. Proceedings of the International Large River Symposium (LARS). Canadian Special Publication of Fisheries and Aquatic Sciences, Ottawa, Canada: 110-127.

LIKENS, G. E. \& F. H. BORMANN. 1995. Biogeochemistry of a Forested Ecosystem. 2nd ed. New York: Springer-Verlag. $160 \mathrm{pp}$.

LOCK, M. A. 1993. Attached microbial communities in rivers. In: Aquatic microbiology: an ecological approach. T. E. Ford (ed.): 113-138. Blackwell Scientific Publications, Oxford, UK.

LOWE, W. H. \& G .E. LIKENS. 2005. Moving headwater streams to the head of the class. BioScience, 55: 196-197.

MALARD, F., K. TOCKNER, M. J. DOLE-OLIVIER \& J. V. WARD. 2002. A landscape perspective of surface-subsurface hydrological exchanges in river corridors. Freshw. Biol., 47: 621-640.

MARGALEF, R. 1991. Teoría de los sistemas ecológicos. Publicaciones Universidad de Barcelona, Barcelona, Spain. 290 pp.

MARGALEF, R. 1997. Our Biosphere. Excellence in Ecology Book 10. Ecology Institute, Oldendorf/Luhe, Germany. 176 pp.

MARTÍ, E., J. ARMENGOL \& F. SABATER. 1994. Day and night nutrient uptake differences in a calcareous stream. Verh. Interna. Verein. Limnol., 25: 1756-1760.

MARTÍ, E., J. AUMATELL, L. GODÉ, M. POCH \& F. SABATER. 2004. Nutrient retention efficiency in streams receiving inputs from wastewater treatment plants. J. Environ. Qual., 33: 285-293.

MARTÍ, E., S. G. FISHER, J. D. SCHADE \& N. B. GRIMM. 2000. Effect of flood frequency on hydrological and chemical linkages between streams and their riparian zones: an intermediate disturbance model. In: Streams and Ground Waters. J. B. Jones, Jr. \& P. J. Mulholland (eds.): 111-136. Academic Press. San Diego, USA.

MARTÍ, E. \& F. SABATER. 1996. High variability in temporal and spatial nutrient retention in Mediterranean streams. Ecology, 77: 854-869.

MCCLAIN, M. E., E.W. BOYER, C. L. DENT, S. E. GERGEL, N. B. GRIMM, P. M. GROFFMAN, S. C. HART, J. W. HARVEY, C. A. JOHNSTON, E. MAYORGA, W. H. MCDOWELL \& G. PINAY. 2003. Biogeochemical hot spots and hot moments at the interface of terrestrial and aquatic ecosystems. Ecosystems, 6: 301-312.

MELACK, J. M., L. L. HESS, M. GASTIL, B. R. FORSBERG, S. K. HAMILTON, I. B. T. LIMA \& E. M. L. M. NOVO. 2004. Regionalization of methane emissions in the Amazon Basin with microwave remote sensing. Glob. Change Biol., 10: 530-544.

MERSEBURGER, G. C. 2006. Nutrient dynamics and metabolism in Mediterranean streams affected by nutrient inputs from human activities. $\mathrm{PhD}$ thesis. Barcelona University. 223 pp.

MERSEBURGER, G. C., E. MARTÍ \& F. SABATER. 2005. Net changes in nutrient concentrations below a point source input in two streams draining catchments with contrasting land uses. Sci. Total Environ., 347: 217-229.

MEYBECK, M. 2003. Global analysis of river systems: from Earth system controls to Anthropocene syndromes. Phil. Trans. R. Soc. Lond. B, 358: 1935-1955. 
MEYER, J. L., M. J. PAUL, W. K. TAULBEE. 2005. Stream ecosystem function in urbanizing landscapes. J. N. Am. Benthol. Soc., 24: 602-612.

MULHOLLAND, P. J. 2004. The importance of instream uptake for regulating stream concentrations and outputs of $\mathrm{N}$ and $\mathrm{P}$ from a forested watershed: evidence from long-term chemistry records for Walker Branch Watershed. Biogeochemistry, 70: 403-426.

MULHOLLAND, P. J., J. D. NEWBOLD, J. W. ELWOOD, L. A. FERREN \& J. R. WEBSTER. 1985. Phosphorus spiralling in a woodland stream: seasonal variations. Ecology, 66: 1012-1023.

NAIMAN, R. J . \& H. DÉCAMPS. 1997. The ecology of interfaces: riparian zones. Ann. Rev. Ecol. Syst., 28: 621-658.

NEWBOLD, J. D., J. W. ELWOOD, R. V. O'NEILL \& W. VAN WINKLE. 1981. Measuring nutrient spiralling in streams. Can. J. Fish. Aquat. Sci., 38: 860-863.

O'NEILL, R. V., A. R. JOHNSON \& A. W. KING. 1989. A hierarchical framework for the analysis of scale. Landsc. Ecol., 3: 193-205.

PACKMAN, A. I., \& J. S. MACKAY. 2003. Interplay of stream-subsurface exchange, clay particle deposition, and streambed evolution. Water Resour. Res., 39: 1097.

PALMER, M., E. BERNHARDT, E. CHORNESKY, S. COLLINS, A. DOBSON, C. DUKE, B. GOLD, R. JACOBSON, S. KINGSLAND, R. KRANZ, M. MAPPIN, M. L. MARTINEZ, F. MICHELI, J. MORSE, M. PACE, M. PASCUAL, S. PALUMBI, O. J. REICHMAN, A. SIMONS, A. TOWNSEND \& M. TURNER. 2004. Ecology for a crowded planet. Science, 304: 1251-1252.

PETERSON, B. J., R. M. HOLMES, J. W. McCLELLAND, C. J. VÖRÖSMARTY, R. B. LAMMERS, A. I. SHIKLOMANOV, I. A. SHIKLOMANOV \& S. RAHMSTORF. 2002. Increasing river discharge to the Arctic Ocean. Science, 298: 2171-2173.

PETERSON, B. J., W. M. WOLLHEIM, P. J. MULHOLLAND, J. R. WEBSTER, J. L. MEYER, J. L. TANK, E. MARTÍ, W. B. BOWDEN, H. M. VALETT, A. E. HERSHEY, W. H. McDOWELL, W. K. DODDS, S. K. HAMILTON, S. GREGORY \& D. D. MORRALL. 2001. Control of nitrogen export from watersheds by headwater streams. Science, 292: 86-90.

POOLE, G. C. 2002. Fluvial landscape ecology: addressing uniqueness within the river discontinuum. Freshwat. Biol., 47: 641-660.
POSTEL, S. L. 1998. Water for food production: will there be enough in 2025? BioScience, 48: 629-637.

RAUTER, A., G. WEIGELHOFER, J. WARINGER \& T. J. BATTIN. 2005. Transport and metabolic fate of sewage particles in a recipient stream. $J$. Environ. Qual., 34: 1591-1599.

RAYMOND, P. A., \& J. E. BAUER. 2001. Riverine export of aged terrestrial organic matter to the North Atlantic Ocean. Nature, 409: 497-500.

RICHEY, J. E., J. M. MELACK, A. K. AUFDENKAMPE, V. M. BALLESTER \& L. L. HESS. 2002. Outgassing from Amazonian rivers and wetlands as a large tropical source of atmospheric CO2. Nature, 416: 617-620.

SABATER, F., A. BUTTURINI, E. MARTÍ, I. MUÑOZ, A. ROMANÍ, J. WRAY \& S. SABATER. 2000. Effects of riparian vegetation removal on nutrient retention in a Mediterranean stream. $J . N$. Am. Benthol. Soc., 19: 609-620.

SABATER, F. \& E. MARTÍ. 2002. Towards a holistic view of nutrient dynamics in fluvial ecosystems. 2001. Verh. Internat. Verein. Limnol., 27: 3111-3116.

SABATER, S., A. BUTTURINI, J. C. CLEMENT, T. BURT, D. DOWRICK, M. HEFTING, V. MATRE, G. PINAY, C. POSTOLACHE, M. RZEPECKI \& F. SABATER. 2003. Nitrogen removal by riparian buffers along a European climatic gradient: patterns and factors of variation. Ecosystems, 6: 20-30.

SABATER, S., H. GUASCH, A. ROMANÍ \& I. MUÑOZ. 2002. The effect of biological factors on the efficiency of river biofilms in improving water quality. Hydrobiologia, 469: 149-156.

SAHIN, V. \& M. J. HALL. 1996. The effects of afforestation and deforestation on water yields. $J$. Hydrol., 178: 293-309.

SÁNCHEZ-PÉREZ, J. M. \& M. TRÉMOLIÈRES. 2003. Change in groundwater chemistry as a consequence of suppression of floods: the case of the Rhine floodplain. J. Hydrol., 270: 89-104.

SCHADE, J. D., J. R. WELTER, E. MARTÍ \& N. B. GRIMM. 2005. Hydrologic exchange and $\mathrm{N}$ uptake by riparian vegetation in an arid-land stream. J. N. Am. Benthol. Soc., 24: 19-28.

SCOTT, M. C., G. S. HELFMAN, M. E. MCTAMMANY, E. F. BENFIELD \& P. V. BOLSTAD. 2002. Multiscale influences on physical and chemical stream conditions across blue ridge landscapes. J. Am. Water Resour. Assoc., 38: 1379-1392.

SIMON, A. \& A. J. C. COLLISON. 2002. Quantifying the mechanical and hydrologic effects of riparian vegetation on streambank stability. Earth Surf. Process. Landf., 27: 527-546. 
SIMON, K. S., C. R. TOWNSEND, B. J. F. BIGGS \& W. B. BOWDEN. 2005. Temporal variation of $\mathrm{N}$ and $\mathrm{P}$ uptake in $2 \mathrm{New}$ Zealand streams. J. N. Am. Benthol. Soc., 24: 1-18.

SPARKS, R. E. 1995. Need for ecosystem management of large rivers and their floodplains. BioScience, 45: 168-182.

STANLEY, E. H., S. G. FISHER, N. B. GRIMM. 1997. Ecosystem expansion and contraction in streams. BioScience, 47: 427-435.

STREAM SOLUTE WORKSHOP. 1990. Concepts and methods for assessing solute dynamics in stream ecosystems. J. N. Am. Benthol. Soc., 9: 95-119.

SWEENEY, B. W., T. L. BOTT, J. K. JACKSON, L. A. KAPLAN, J. D. NEWBOLD, L. J. STANDLEY, W. C. HESSION \& R. J. HORWITZ. 2004. Riparian deforestation, stream narrowing, and loss of stream ecosystem services. Proc. Natl. Acad. Sci. U.S.A., 101: 14132-14137.

TOCKNER, K., F. MALARD \& J. V. WARD. 2000. An extension of the flood pulse concept. Hydrol. Process., 14: 2861-2883.

TOCKNER, K., D. PENNETZDORFER, N. REINER, F. SCHIEMER \& J. V. WARD. 1999. Hydrological connectivity, and the exchange of organic matter and nutrients in a dynamic river-floodplain system (Danube, Austria). Freshw. Biol., 41: 521-535.

VALETT, H. M., M. A. BAKER, J. A. MORRICE, C. S. CRAWFORD, M. C. MOLLES, Jr., C. N. DAHM, D. L. MOYER, J. R. THIBAULT \& L. M. ELLIS. 2005. Biogeochemical and metabolic responses to the flood pulse in a semiarid floodplain. Ecology, 86: 220-234.

VALETT, H. M., J. A. MORRICE, C. N. DAHM \& M. E. CAMPANA. 1996. Parent lithology, groundwater-surface water exchange and nitrate retention in headwater streams. Limnol. Oceanogr., 41: 333-345.

VENTERINK, H. O., F. WIEGMAN, G. E. M. VAN DER LEE \& J. E. VERMAAT. 2003. Role of active floodplains for nutrient retention in the river Rhine. J. Environ. Qual., 32: 1430-1435.

VITOUSEK, P. M., H. A. MOONEY, J. LUBCHENCO \& J.M. MELILLO. 1997. Human domination of Earth's ecosystems. Science, 277: 494-499.

WALSH, C. J., A. H. ROY, J. W. FEMINELLA, P. D. COTTINGHAM, P. M. GROFFMAN \& R. P. MORGAN II. 2005. The urban stream syndrome: current knowledge and the search for a cure. J. N. Am. Benthol. Soc., 24: 706-723.

WEBSTER, J. R., S. W. GOLLADAY, E. F. BENFIELD, J. L. MEYER, W. T. SWANK \& J. B. WALLACE. 1992. Catchment disturbance and stream response: an overview of stream research at Coweeta Hydrologic Laboratory. In: River Conservation and Management, P. J. Boon, P. Calow \& G. E. Petts (eds.): 231-253. John Wiley $\&$ Sons, New York, USA.

WEBSTER, J. R. \& B. C. PATTEN. 1979. Effects of watershed perturbation on stream potassium and calcium dynamics. Ecol. Monogr., 49: 51-72.

WIENS, J. A. 2002. Riverine landscapes: taking landscape ecology into the water. 2002. Freshw. Biol., 47: 501-515.

WITHERS, P. J. \& E. I. LORD. 2002. Agricultural nutrient inputs to rivers and groundwaters in the UK: policy, environmental management and research needs. Sci. Total Environ., 282-283: 9-24.

WOLlHEIM, W. M., B. J. PETERSON, L. A. DEEGAN, J. E. HOBBIE, B. HOOKER, W. B. BOWDEN, K. J. EDWARDSON, D. B. ARSCOTT, A. E. HERSHEY \& J. FINLAY. 2001. Influence of stream size on ammonium and suspended particulate nitrogen processing. Limnol. Oceanogr., 46: 1-13.

ZAK, D. R., K. S. PREGITZER, W. E. HOLMES, A. J. BURTON \& G. P. ZOGG. 2004. Anthropogenic N deposition and the fate of ${ }^{15} \mathrm{NO}_{3}{ }^{-}$in a northern hardwood ecosystem. Biogeochemistry, 69: 143-157. 